\title{
Eric Wolf: the crosser of boundaries
}

\author{
Irene Portis-Winner \\ Massachusetts College of Art \\ 621 Huntington Avenue, Boston, MA 02115, USA \\ e-mail: tgipwinner@mediaone.net
}

\begin{abstract}
The subject of this paper is an introduction to my assessment of the work of the late American anthropologist, Eric Wolf (1923-1999), whom I consider to be one of the greatest American anthropologist. I plan a monograph on his total work from a point of view, largely overlooked, emphasizing his sensitive, path-breaking, and poetic insights. I see Wolf's work as having three interpenetrating periods, which I call (1) Eric Wolf, the poet, focusing primarily on his work on Mexico, (2) the study of peasantry world-wide, emphasizing history, context, power, etc. (from the very beginning Wolf demolished the idea of static isolated cultures that anthropologists so loved to study; and in this respect, Eric Wolf changed anthropology forever), and (3) the third period, reaching to his death and never really finished, was Wolf the philosopher and crosser of boundaries.
\end{abstract}

Eric R. Wolf (1923-1999), the pioneer in anthropological studies of the peasant and the larger society, was a many-sided and imaginative scholar. He did not shirk challenges and complexities and never limited to expediencies the problems he investigated, thus facilitating easier but less useful solutions. Nor did his questioning mind stop exploring ever-widening and ever-changing theories. Shall we say that he was oblivious of turf guarding? He looked beyond official knowledge and the accepted span of anthropological concerns, thus rejecting the concept of closed and static societies and insisting on the importance of context and history, local and world-wide. I locate him, in the worlds of Franz Boas, and Margaret Mead, and intertextually also with that of with the philosopher Charles Sanders Peirce, and those of two important representatives of the aesthetics of the Prague Linguistic Circle, namely Roman Jakobson, particularly Jakobson's 
theory of metonymic metaphors, and Jan Mukařovský, with whom he shared a far-sighted and expanding exploration of the interpenetration of cultures. I also see important intertextual relations with Juri Lotman, the leader until his death of the Moscow-Tartu school, particularly Lotman's theory of montage, history, myth, and semiotics of everyday behavior, and with M. Bakhtin notably his carnival, reversals of hierarchies and oppositions of official and unofficial levels of cultures.

Sons of The Shaking Earth (1959), Wolf's first book, and the primary example I discuss in this essay, strikingly demonstrates the poetic bent in Wolf's work, since the text is replete with tropes, and we find parallels to Lotman's explicit montage, that is the juxtaposition of oppositions which reveal new similarities as well as Lotman's conception of the hero of a narrative who crosses boundaries as opposed to those dramatis personae who remain essentially static and rule-bound. In Wolf's works the heroes are both the ethnologist and those boundary-crossing actors as conceptualized by the author. In his later works, the relation of Wolf's ongoing development of his theoretical stance and philosophical concepts to those to the above semiotic and pre-semiotic thinkers, is a fertile field to investigate which I can only touch on in this essay.

The above remarks are hardly the conventional assessment of Wolf, who has usually been classed as an economic, political and structural anthropologist with a bent toward Marxism, and is associated with Sidney Mintz, Marshall Sahlins, George Foster, Robert Redfield, and others, which was not inappropriate particularly in the mid-years of his career when he was attempting to analyze the structural changes of peasant societies, although he never omitted context, history, and dynamics. For Wolf the stimulating interplay of domains of culture, including complex meanings, symbolic and ritual performances, values, ideologies, and inner view of the members of the community studied were never to be ignored, and of focal importance were their interrelations with the economic and political structure, for Wolf was a never a reductionist or determinist. Indeed the traditional assessment of Wolf's work was not sensitive to the many implications of his sophisticated dynamic positioning of peasantry in the larger society and looking at the world through the point of view of the interlocutors and not just that of the author. Consider the parallels between Wolf's rescue of history, official and unofficial, for the study of cultures, and the interpenetration, not isolation, of cultures, in Lotman's and Uspenskij's semiotics of history (cf. Nak- 
himovsky, Nakhimovsky 1985). Their works were translated only relatively recently and, as far as I know, were not studied by Wolf. Wolf wrote in his Preface to Europe and the People Without History:

In 1968 I wrote that anthropology needed to discover history [...]. We can no longer be content with writing only the history of victorious elites or with detailing the subjugation of dominant ethnic groups [...]. We [...] need to uncover the history of "the people without history" - the active histories of "primitive" peasantries, laborers, immigrants, and besieged minorities [...]. [This] book strives to cross the lines of demarcation that separate the various human disciplines from one another, and to abrogate the boundaries between Western and non-Western history. It was written in the belief that a better understanding of our human condition was now within our grasp [...]. (Wolf 1982b: ix-x)

To some extent Wolf was attracted also to Foucault's writings on structural power though Wolf also always emphasized the concept of culture. Nor did he dismiss the entirety of the Enlightenment (Wolf: 2001: 384).

With these introductory remarks, I propose three main streams in Wolf's thinking, which are interpenetrating and only relatively chronological. (1) Wolf the sensitive poet, exemplar of which is his early study of Mexico, Sons of the Shaking Earth (1959). This first and never really absent strain demonstrates Wolf's fascination with the ambiguities of cultural meanings and cultural polysemy. (2) The second important aspect of Wolf's thinking was that of the economic political revolutionary anthropologist who abolished forever the notion of the isolated peasant village and, by implication, that of the isolated tribe. Context, time and space were not overlooked. (3) The third strain is Eric Wolf the theoretician and philosopher who considered power in relation to some semiotic concepts particularly in his last work, Envisioning Power (1999).

I shall return to the first strain in the concluding section of this essay when I discuss Sons of the Shaking Earth. But first let us assess Wolf the scholar and some recent articles considering him. Globalism which has become an ambiguous term is an extreme resolution of the path Eric Wolf took, but in so far as globalism dispenses with cultural differences and implies universal conformism to American commercialism and the values associated with it, it is hardly akin to Wolf's world-wide cultural universe. For Wolf the passive isolated peasant or village was replaced by peasantries situated in world history, often revolutionary, creative and interesting, and hardly Marx's contemptuous view of peasants as mere sacks of potatoes; although the peasant 
was not necessarily idealized. Though Wolf wished to bring to the fore the often neglected underdog, he did not oversimplify since he never omitted the underlying socio-economic and cultural factors contributing to causes of conflict and revolution.

Let us look at an analytical essay by Wolf and some relevant discussions that elucidate the recent controversies concerning power and culture in his strong critique (Wolf 1988) of the conventional understanding of such terms as society and nation. Here Wolf held that the term "society" connotes a Western bourgeois and Marxist view of the modern nation state "which, through its power advantage, indoctrinates its members with the ideology of common social and moral values which then become the essence that cements the totality; and society is then conceived as a bounded and homogeneous whole made up of interacting units" (Wolf 1988: 752). This view does not satisfy Wolf, for it assumes that one society or nation necessarily shares a unified culture and history. Rather, Wolf argues that "from primitives on, intersecting and fluid networks created by various changing bonds are the more ambiguous, more complex, but also more realistic, phenomena that characterize societies" (Wolf 1988: 760). Decrying traditional architectural metaphors to describe "nexuses of interaction", Wolf invokes Lacan's "upholstery" (Lacan 1966: 502 in Wolf 1988: 757) that through its spaced buttons designates key points in chains of significations, a metaphor that exemplifies the kind of inventive leap that anthropologists might emulate.

While for Wolf the concept of society has "become a hindrance in our search for more knowledge since [it] sets itself up as an eternal verity" (Wolf 1988: 759), he warns that dissatisfaction with this concept as a total system should not lead to substituting for it the individual as a total system. I quote Wolf's following critique because it expresses very succinctly Wolf's temperament and his insightful critical mind. Wolf sees neither society nor the individual as a timeless essence. For Wolf the

abstract individual is merely another monad, a timeless and reified essence like the conceptual entity it is supposed to criticize and oppose. Real-life individuals, in contrast, in the many different cultural settings that we know about, are differentially constructed out of ancestors, parents, kinsmen, siblings, role models, spirit guardians, power animals, prenatal memories, dream selves, reincarnated spirits, or gods taking up residence in their heads and riding them like divine horsemen [...]. We need to invent new ways of thinking about heterogeneity and the transformative nature of human arrangements and to do so scientifically and humanistically at the same time. 
The attempt to understand what humans do and conceive economically, politically, socially, morally, cognitively and emotionally all at once has always been a hallmark of anthropology, and the goal remains a usable and productive program. (Wolf 1988: 760)

Others have voiced more clear pessimism about success of writings in ethnology, and of course all this preceded the events of September 11, 2001. Thus how prophetic are the warnings of Hammel when he asks whether the disasters in the former Yugoslavia may spell the end of anthropology as we know it, and that perhaps Boas was wrong. Hammel writes:

Our adherence to the antiracist principles enunciated by Boas and later by Mead, Kluckhohn, and others [...] may be on a collision course with the reemergence of ethnicity (sometimes symbolized as religion) as the backbone of political and social organization [...]. The problem is thus [...] bigger than Yugoslavia. But it is also bigger than the convenient use of ethnic particularism as a replacement for universalistic rationality [...]. It raises some fundamental problems for us as anthropologists, especially in the important area of human rights. [...] It means that you can be a citizen based on where you live rather than on where you came from. [...] Cultural relativism is in my view a worthless concept when the issues are those of life and death, of personal degradation, of all of those values that are at the core of our own concepts of civil and human rights. [...] What if Boas [...] was wrong? (Hammel 1994: 48)

I do not suggest that Eric Wolf shared this drastic pessimism but surely his hope for cultural anthropology was tempered by such reservations.

As a general introduction to the recent and changing assessments of Wolf's work, I look at three recent articles by Wolf's colleagues, two written before his death, the first by Jane Schneider, the second by Ashraf Ghani both in a collection by Schneider and Rapp (1995) devoted to Wolf's influence on anthropological thinking. Thirdly, I look at a review article which appeared after Wolf's death, by Stanley Barrett, Sean Stockholm, and Jeanette Burke (2001) which assesses Wolf's last book, Envisioning Power: Ideologies of Dominance and Crises (1999).

I examine these articles because they reveal a shift in the habitual use and understanding of Wolf's work. These essays attempt to clarify some common misunderstandings relating to Wolf's presumed reductionism and determinism, and the abstract character of his typologies, and take up Wolf's view of the autonomy and interrelation all domains of culture. These essays, while they are broad-ranging, are 
not attuned to the metaphoric and poetic mode and aesthetic values and sign types, and ambiguities of the inner and outer point of view of, which I discern in various writings of Wolf, but nevertheless they account for a richer and more informative exposition of Wolf's oeuvre than most earlier treatments have.

I begin with Schneider (1995), noting her remarks most pertinent to our interests here in her "Introduction: The Analytic Strategies of Eric Wolf". According to Schneider, historical processes for Wolf "are preeminently political and economic, reinforced through ideology" (Schneider 1995: 3). Furthermore, "concentrations of power, however they might be achieved, will continue to act disruptively out of their location in a competitive, ever-changing and unevenly developed "field of forces"' (Schneider 1995: 4). Schneider notes that Wolf has misgivings about the architectural term "structural power" because of its connotation of fixity, and prefers "metaphors from physics" such as vectors, forces, and fields of force (Schneider 1995: 3-4). These terms express his preference for dynamics over statics, "unpredictable, everchanging moves of strategizing and self justifying power holders in 'a world of multi-tiered conflicts" referring to Wolf's essay "Cycles of violence" (Wolf 1987, Schneider 1995: 4). Schneider points out, "this means that for Wolf ideational phenomena belong to the world of politics and economics; they are not its product or "superstructure", (Schneider 1995: 4). Religion is also a symbolic communication that effects politics and economics and may also generate vectors (Schneider 1995: 4). While Wolf has much to say about the destabilizing power of capitalism, he rejects the concept of powerless people since his emphasis on dynamics means that there are forces that enlarge "the possibilities of empowerment from below" (Schneider 1995: 5).

As Schneider notes, Wolf's Peasant Wars of the Twentieth Century (1969d) exemplifies these processes. Local and regional histories are significant. According to Wolf, knowing peasant histories is also a way "to recover a significant part of ourselves, so that we may gain more effective knowledge of the world" (Wolf 1983: 5, Schneider 1995: 7). Schneider holds that "occasionally Wolf has been taken as a 'world system' theorist [...] [but] he faults this approach for obliterating 'range and variety' of the micropopulations 'habitually investigated by anthropologists" (Wolf 1982b: 23, Schneider 1995: 7). Schneider adds that it is this openness that most profoundly marks this dynamic, processual approach to what history is about" (Schneider 1995: 8). For Wolf French structuralism accounts for the 
“" 'ongoing dialectical interpenetration' of social behavior and symbolic form" which have important reciprocal relations with "ecological, economic and organizational context" (Wolf 1986: 327, Schneider 1995: 9), Furthermore, Wolf finds misleading such dichotomies as: tradition/modernity, pre-capitalist/capitalist, pre-colonial/colonial, which do not take into account historical processes while modern/post-modern "collapses the processes of an earlier epoch into a seamless trajectory" (Schneider 1995: 9). Wolf strongly supports an historical comparative approach. I see Wolf as rejecting, as did Boas, arbitrary, evolutionary, unilinear evolutionary histories as opposed to local empirically backed histories, a project which portrays a new kind of world that does not omit the "people without history". As Wolf and Cole write, differences are accounted for by the effect of "the template of ideas for the ordering of social life" (Cole, Wolf 1974: 19, Schneider 1995: 11).

Schneider praises Wolf's emphasis on surprises, "anomalies [...] that do not fit into the pattern" (Schneider 1995: 11). His curiosity led him to see unpredicted cultural behavior. Such phenomena were often overlooked by traditional ethnographers anxious for the data to fit into their preconceived pattern. This recalls Peirce's "surprise" as the basis for the awakening of consciousness of self or secondness, leading to thirdness. In his simplest explanation, Peirce describes the surprise of an infant that touches a hot stove, leading the infant to awareness of self or as, Peirce writes, ego discovers non-ego. In fact, in his later life Wolf began to explore the relation of Peirce's thirdness to culture and power (Wolf 1999: 53-54, and private communications).

Wolf's work during what I have called some what arbitrarily his middle period of his studies focused on structural issues such as peasant coalitions, and patron-client relations, and circular religious and ritual duties organized by the local priest, but he made clear that such structural relations were not meant to be static. None were stable and unchanging. As Schneider notes, "contrasting examples are viewed as local and creative responses to divergent vectors or forces". For example, "such vectors helped to shape the compadrazgo (men linked in involvement of child's baptism) and fiesta systems in Mexico and other Latin American peasantries" (Schneider 1995: 15) and similar systems in other peasant areas.

Underlining the importance of differences, not only in smaller communities but in between nations shaped by the cultural patterns of each group, Wolf saw these relations as "represented by symbols standing for norms of relations between people or they may be 
'symbolic pantomimes' (Veblen)" (Mintz, Wolf 1950, in Schneider 1995: 23). Pantomime was also an important form of symbolic behavior for Uspensky and Lotman. In a related statement Wolf cautioned that "to have effective results [...] requires a study of the things, peoples or relations to which they refer" (Mintz, Wolf 1950, in Schneider 1995: 23). We see that in his earliest writings Wolf rejected such concepts as empty or purely arbitrary symbols and upheld their relation to reality to which they refer, which of course was also a part of Peirce's program where symbols, always having an iconic and indexical level, were never purely arbitrary. Another important contribution to dynamics of symbols is Wolfs concept of the significant roles of "interstitial brokers" in Mexico which he "portrayed as catalysts in spreading the syncretic myth of the Virgin of Guadalupe" - a potent symbol of the 'salient social relations' of Mexican life as against the relationships to metropolitan Spain (Wolf 1958, Schneider 1995: 24). Brokers also established a symbolic frame at the time of the demise of the hacienda system. Such interstitial manipulators, as Wolf suggested are significant in complex societies and may account for cultural differences in spite of formal similarities (Wolf 1996 in Schneider 1995: 24). Additionally the role of intellectuals, often marginal in colonial regimes, takes on new roles under change as the dominant power takes over but this takes beyond the province of this discussion.

The second article we discuss is an assessment of Wolf's book, Envisioning Power: Ideologies of Dominance and Crises (1999), reviewed by Stanley R. Barrett, Sean Stokholm and Jeanette Burke (2001). The reviewers hold that Wolf's "aim is to salvage culture by fusing it analytically to power" (Barrett et al. 2001: 468) and that ideas are fundamental to culture. Quoting Wolf, the reviewers note that by ideas Wolf means "the entire range of mental constructs rendered manifest in public representations" while ideology means "unified schemes of configurations developed to underwrite or manifest power" (Wolf 1999: 4, Barrett et al. 2001: 469). In a complex arguments the reviewers ask if Wolf accepts the idea that the concept of culture accounts for the universalism of the Enlightenment or does it involves the particularism and differentiation of CounterEnlightenment. Wolf accepts the latter in modified form because of the relational value of culture, which brings together many different aspects of culture. (Wolf 1999: 67, in Barrett et al. 2001: 469). It is apparent that Wolf accepts some aspects of the Enlightenment as well 
as its counter forces. We are caught once more in essentially false dichotomies.

The reviewers ask how Wolf salvages the concept of culture?

The first step is to follow the critics by redefining culture to emphasize diversity, ambiguity, contradiction and imperfectly shared meanings and knowledge. The second step is to 'cure' or 'energize' culture by injecting power into it, rendering it robust and potent, finally capable of realizing lofty explanatory demands [...]. (Barrett et al. 2001: 469)

Wolf takes up three cases, the Kwakiutl, the Aztecs, and Hitler's National Socialism. While the reviewers feel these are not the best choices, for us the main issue in the test cases is Wolf's emphasis for the Kwakiutl of sacred time and the mythological as opposed to Benedicts theme of the bellicose. For the Aztecs, Wolf discusses the relation of power to ideas, public rituals and the perception of the cosmic. Pertaining to the Nazis inner Wolf looks to essence or Geist that pervades the violent ideology.

In the concluding theoretical discussion the reviewers note that Wolf eschews an attempt to produce a formal theory of power and opts for analyzing power after the fact, and they criticize Wolf's theory of cultural power as not complete, since his cases were all focused on power and there was no example of an opposing case, but they hail Wolf's argument that ideas, social relations and power are interdependent and that for him the materialist realm and idealist realm carry equal causal weight. He argues that ideas are the key feature to human existence (Barrett et al. 2001: 475). The fundamental assertion of Wolf is that it is not culture or power but culture and power. In spite of their positive evaluation of Wolf's theoretical approach, the reviewers remark that Wolf may be reducing culture to ideas. I believe this is a specious argument that clouds the issue, since in what sense are ideas not a part of culture? But this has been a murky area for much anthropological theory. In contrast the Lotman approach does not see ideas as separate from culture and it seems to me Wolf was moving in that direction.

We now turn to the third article by Ashraf Ghani (1995), entitled "Writing a history of power: As examination of Eric R. Wolf's anthropological quest". Ghani sees Wolf's "cumulative praxis is an endeavor to analyze the intersection of power and culture in the history of the present" (Ghani 1995: 31). Expanding this thought, Wolf calls for "the systematic writing of history in the modern world in which we spell out the history of power which created the present 
day cultural systems and linkages between them" (Wolf 1969a: 10, in Ghani 1995: 32).

As Ghani points out Wolf, like Schneider, rejects architectural metaphors for web- like connections since he turns to metaphors that are more relational. As Ghani quotes Wolf, "once we look at phenomena as points of intersection between multiple vectors, we need to stress opposition as well as convergence, dislocation as well as cohesion, disintegration as well as integration, on the micro-level as well as on the macro-level of analysis" (Wolf 1977, in Ghani 1995: 32).

As Wolf expanded, "power is [...] never external to signification. [...] It inhabits meaning and is its champion in stabilization and defense.[...] [For] symbolic work is never done, achieves no final solution" (Wolf 1990: 593, Ghani 1995: 33). Here this thought echoes Peirce's notion of infinite regress (that is to elucidate meaning every interpret requires another one and there is no end), and while I do not know when Wolf began to investigate Peirce, I believe this is at least an example of parallel thought.

"Writing the history of the present" was also called for by Foucault, but Foucault did not involve culture as central, nor did he concern himself with processes and uneven developments in all aspects of culture as did Wolf. Reminding us of Mukařovský's insistence that cultures were forever being penetrated by changes from the outside, Wolf argues that "in the majority of cases the entities studied by anthropologists owe their development to processes that originate outside them [...] are affected by their demands and affect them in turn" (Wolf 1982a: 9, Ghani 1995: 35). We note that such a dynamic approach is far removed perceptions of closed communities, nor is it akin to the processes of automatic diffusion. As Levi-Strauss has shown in his tomes on mythology influences go both ways and are subject to transformations in terms of the particular cultural beliefs, and particular environments. The interrelation of cultures and the world outside is forever stressed by Wolf, for he sees a community not as closed but as a "local termini of a web of relations" extending from the community to the nation (Wolf 1956: 1056; Ghani 1995: 37).

Wolf's contribution to a dynamic study of peasantry can hardly be overestimated. As Geertz reflected, anthropology noticed the peasant only recently (Geertz 1961: 1, in Ghani 1995: 38). Wolf's assessment of peasant culture rejects Marxist economic determinism and confinement of culture to the superstructure and of course the lumping of pea- 
sants as a sack of potatoes, although he interprets some Marxist insight, but with limitations.

Turning to Sons of the Shaking Earth, Ghani notes that for Wolf it is "an attempt to trace the life line of a culture" (Wolf 1959: vii; Ghani 1995: 42). The pattern of power relations is metaphorically described as "galactic systems" bringing villages and towns into the orbit of an expanding state, but galaxies may break up into solar systems (Wolf 1959: 256, in Ghani 1995: 43). This depiction does not imply timelessness, for Wolf sees the ethnographic present as a battle ground between the past and the future, "and there can be no finish to this book, nor any prophecy” (Wolf 1959: 256, Ghani 1995: 43).

Describing focal features of the Mexican culture Wolf emphasizes the Mexican religious calendar that was controlled by the priesthood, which set the time for the various tasks of cultivation and these were geared to rituals and to cosmic time. The Spain rule changed the system radically. As Wolf wrote "[...] it would be a planned world, projected into reality by the royal will and its executioners. Thus utopia would become law and law utopia" (Wolf 1959: 162-163, Ghani 1995: 44).

The failure of this utopia is dramatized in Wolf's Sons of the Shaking Earth and Wolf's and Hansen's The Human Condition in Latin America. The attempt is to cede the voices other than the voice of the other a central place in the text" (Ghani 1995: 44). The oppressive conditions under the Spanish caused people "to rely on more intimate and more assured ties of kinship, friendship and personal acquaintances" (Wolf, Hansen 1972: 1200, in Ghani 1995: 44) which I note is an apt observation explaining the kinds of social relations in oppressive communist society where one compensation was the maintenance of warm friendships.

I conclude with a remark from Wolf's view of Mexico peopled by closed corporate communities that lapsed over time, a perspective that must not be mistaken for earlier anthropological descriptions of the static unchanging village. For Wolf's communities were not reified essences but could only be understood in dynamic interaction between community and nation and that interaction had a history (see Wolf 2001: 147-148).

Before proceeding to my own discussion of Wolf's first book, Sons of the Shaking Earth, I draw on the theme of George Steiner's Norton lectures at Harvard University, "Lessons in the Masters on the Art of Teaching", October-November 2001). Steiner's examples are drawn from Plato and Aristotle, Virgil and Dante, and Faust and Mephis- 
topheles. Steiner's thesis was that the relation between the Master and the Disciple are ambiguous, fraught with danger and deception. But when the Master imparts in the dialogue the apogee, reaching the true and eternal, the art of teaching reaches its heights. And even more dramatic, the student may go beyond the master who opens wide areas to be further explored, never limiting him or herself to a particular design. Applying this to the scholar who is the subject of this study I believe Wolf is an apt exemplar of Steiner's far sighted model of teacher to student. I will not argue over Steiner's "true and eternal" except to say that unless we capitulate completely to the post modern mood, there must be some hope and goal that striving to reach some kind of understanding of humanity justifies the effort. It is my position that in Wolf's final book, Envisioning Power (1999), new channels were opened that had been potentially there to be discovered in many of the earlier writings.

I complete this essay by returning, as a striking demonstration of Wolf's originality and poeticity, to Sons of the Shaking Earth (1959), in which the story of Mexico is not only a history but a poetic narrative foregrounding scene after scene as we are provided with fresh perceptions of the environment and the inner life of the people, their struggles with war like powers, and the complex meanings of their behavior, beliefs and objects that are valued.

I preface my remarks, with the aphorism on the frontal page of Wolfs Anthropology (1974) which opens with "Man be my Metaphor' - Dylan Thomas". I believe this was an underlining point of view in all Wolf's works no matter how subliminal. The Mexicans well exemplify the use of metaphor or myths, the importance of which cannot be over emphasized. Whether the peasantry continued to believe in them literally or not we cannot argue. Nor can we assert that the peasantry discerned one function of myths as control and obscuring of reality on the part of power holders after the early period of peaceful villages. The transformation of meanings and the polysemic and quixotic dramas of a particular myth as it travels from one group to another, and as it changes over time are all as shown by LéviStrauss to be typical in his vast studies of myths of South American Indians. I have already sketched in broad outlines the imaginative provenance of metaphors in Wolf's description of Mexican peasantry including utopia, galactic and solar systems and corporate communities.

We now look at the first chapters of the book primarily, taking us to the period of the Conquest, as space does not allow an analysis of 
the entire monograph. As Wolf writes in his Preface, three chapters deal with the geographic setting, the biology of the people and their languages, four trace the pre conquest history and the final four are devoted to the effect of the conquest. But as a clue to the particular sensitive quality of this book, note Wolf's statement that "my aims have also been personal. Middle America has also been a personal experience; and in my writing I have attempted to convey something of the quality of this experience" (Wolf 1959: vii). It is my contention that he does admirably achieve this, a goal of which ethnologists today are coming to realize the importance, that is an accounting for the authorial voice and point of view is a part of the portrait and cannot be invisible. I quote in full the opening text that embodies the most sacred beliefs and philosophies that is ascribed to Hungry-Coyote (Netzahualcoyotl), King of Texcoco (1431-1472).

Nothing is so perfect that it does not descend to its tomb.

Rivers, rivulets, fountains and waters flow, but never return to their joyful beginnings;

anxiously they hasten on to the vast realm of the rain god.

As they widen their banks, they also fashion the sad urn of their burial.

Filled are the bowels of the earth with pestilential dust once flesh and bone, once animate bodies of men who sat upon thrones, decided cases, presided in council, commanded armies, conquered provinces, possessed treasure, destroyed temples, exulted in their pride, majesty, fortune, praise and power.

Vanished are these glories, just as the fearful smoke vanishes that belches forth from the infernal fires of Popocatepetl.

Nothing recalls them, but the unwritten page.

Netzahualcoyotl (as cited in Wolf 1959)

This is a poetic lament metamorphosing past deeds vanishing like smoke. We should note that it does not account for oral memories assuming the deeds were so long in the past that they could not be recalled, but we know that oral recollections can be powerful sources. However, the deeds described were those of the ruling elite and the memories of peasants have a different story to tell.

The chapters of this narrative are presented as ethnographic, historic and cultural studies but its language differs markedly from that of the traditional anthropological depictions. Wolf opens the story with striking myths painting the ecological geographic shelf under Mexico. 
Middle American rises out of the sea, its plateau forms one of the roofs of the world, the great volcanoes rise above the landscape clad in a mantle of snow as if they had relinquished their dark powers and fallen into eternal sleep. But the crust of the land is still unstable. It trembles even when asleep and over night a fiery monster may burst forth in a man's field [...]. (Wolf 1959: 1)

Chapter one describes the geographic setting and the pyramids erected by the rulers employing the local peoples. As Wolf writes, "the ancient prophets of this land spoke of five great period of time, each destined to end in disaster" (Wolf 1959: 1). The fifth period, our own, will end with a cataclysmic earthquake. Resembling the mountains, massive pyramids were erected. The largest man-made pyramid in the world, Cholula, is "banished into the foundations of the new churches" and the old gods of Cholula now sleep banished by Pueblo, the most Catholic town in the realm (Wolf 1959: 6). "The city of Toluca itself, located at 8,600 feet above sea level, is the capital of the state of Mexico and a great sprawling settlement into which the Indians of the surrounding country breathe life once a week in the great Friday market" (Wolf 1959: 7). Here "breath" may be seen as a metaphor for the periodic changing market and it is also indexical for the market itself. There are many other tropes in this chapter as for example "the dusty villages cling to the mountainside with the tenacity of the cactus and the prickly pear" (Wolf 1959: 10). The juxtaposition of the village and the prickly pear and the cactus, is a striking metaphor.

Describing, in liberal use of metaphoric language, the changing dominations of different centers during this early period (Teotihuacan, Tula, Peten, etc) the most enduring of which was the valley of Mexico (Wolf 1959: 19), central areas draw villages and town of the periphery "like a magnet" (Wolf 1959: 20). Thus growing states emerge but the process was reversible. In equally metaphorical language Wolf concludes Chapter 1:

Through widening conquests and widening trade the solar system of the favored area becomes a galaxy [...]. But the process is reversible. [...] The cohesion of the center depends [...] upon the pull of its center. [...] The satellite systems [may] slip again from their orbits. [...] In this way galaxies again yield to solar systems. [...] Thus, on the face of this land, human societies have grown and declined in continuous pulsations [...] in continuous tension between expansion and decay. (Wolf 1959: 20)

Chapter Two, entitled the "Generations of Adam" presents a survey of the consequences of the Spanish conquest. A primary fact is that, more than two-thirds of the Indian population died between 1519 and 
1650 (Wolf 1959: 30). As a result the Indians became "mestizos" a mixture of Indian, African, Spanish, and to some extent other Europeans.

A new and very different society with many complexities emerged after the Conquest, the description of which begins in Chapter Eight, but before this chapter, Wolf, true to his fidelity to the importance of history, provides three chapters outlining the period before the Conquest from the earliest seed-planters, to the growth of life centered around villages in the second half of the second millennium as primitive farmers developed into a peasantry, when an emergent state controlled the communities.

However, as Chapter Five relates, until 900 the community remained the autonomous unit but such units were fundamentally altered in the years to follow. As Wolf wrote,

Empires and conquests sweep over the land, cities arise, new gods announce salvation, but in the dusty streets of the little villages a humble kind of life persists, and rises again to the surface when the fury of conquest is stilled, when the cities crumble into ashes, and when new gods are cast into oblivion.

(Wolf 1959: 68)

This description exemplifies Wolf's art of prose where the visual and the verbal complement each other bringing a panorama to life for the inward eye of a reader. Thus all signs tell us of the beginning of the end of this simple life in the village as the modern world "is engaged in severing ties [...] which bind people into local unity in commiting them to complete participation in the Great Society" (Wolf 1959: 68).

The remainder of chapter Five turns back to 900 B.C. and the changes that follow when the egalitarian life of the farming villager becomes more complex and a Middle American society emerged (Wolf 1959: 70). The priesthood developed a powerful and specialized role, large scale constructions are erected for religious purposes, artistic styles are evident. Important examples are the clay figurine and the jade jaguar. Wolf proposes that the jaguar "is a symbol of domination not only of the sacred orifices of the earth but also over their human counterparts" (Wolf 1959: 73). In the theocratic period the centers were temples and the metropolitan Teotihuacan. Priest rulers and specialists that organized labor and tribute and worship of the villagers were the powerful figures. The following passage again exemplifies Wolf's power of imagery and generalization that in a few lines encapsulates pages of factual information. Describing the character of early states he writes they were a combination of terror 
and supernatural power and were responsible for upholding the balance of the universe. The rulers, kings etc had divine power. "They stood before their awed subjects in the splendor and terror of their godhead, but they also showered upon their subjects the benefits of peace and of a well-ordered social life, which was but an aspect of the well-ordered universe" (Wolf 1959: 79). This was a relatively peaceful period as compared to the later Militaristic period (A.D. 7501519).

Continuing the theocratic period, Wolf brings the symbolism of the temple to life. The tiers of the temple equated with the tiers of the universe, the pyramid signifies the mountain of the sky or magical animals as the hummingbird and the jaguar. Other animals have other symbolic meanings. The accomplishment of the calendar systems "serve to bind [...] cosmic time, to domesticate it, as religion domesticates other aspects of the universe [...] reduced to the mere sequence of social time"(Wolf 1959: 87-88).

We know that time calculations were of focal interest to early civilizations and the metaphoric use of "domesticate", its juxtaposition to "time", bears relation to Lotman's assertion that poetic language has more information than ordinary prose. The theocratic period was one of florescence of art architecture and the high development of symbolism. Then followed The Militarist period beginning in 750 lasting to 1519 , the onset of the conquest.

I limit myself to a few remarks about the Mexican narrative following our discussion of chapter Five, "Villages and holy towns". The remaining analysis laid aside for the longer study. Summarizing the dramatic story of Mexico, in his highly depictive and vivid and at the same time powerfully generalizing prose, Wolf wrote:

Each age bears its own mark, and yet each age is merely a bridge between what is past and what is still to be. The Theocratic societies of Middle America are strongly characterized, and yet transient between the simpler societies that preceded them and the Militarist societies that replaced them. Every society is a battlefield between its own past and its future; it was such a conflict that opened the fissures in the Theocratic edifice. (Wolf 1959: 106)

Since this discussion does not pretend to be a history of Mexico although Wolf's book certainly is, but an interpretation of Wolf's a highly poetic and metaphoric style and potent generalizations all based on facts or beliefs of the people and Wolf's creative and imaginative mind, I limit myself here to a brief comment upon. The Mexicans empire builders and rulers of the "Mexica" domain. The following 
passages exemplify Wolf's creative harnessing of myth of a people which provides sharp insight into their mentality.

Referring to the "Mexica" he wrote that

According to their legends, they were led to the site by their Hummingbirdon-the-Left, who ordered them to settle where they saw an eagle sitting on a cactus devouring a snake, There the Mexicans would come face to face with their destiny. There they would fight a holy war in support of the sun, against the forces of night and evil. As each night the sun gave battle to the multitude of stars, so we Mexicans would capture prisoners of war and sacrifice them; each prisoner would represent one star. Fit astral food to sustain the sun in its perilous fight. Painted black and white and wearing a black mask to symbolize the night sky, each victim would mount a holy pyramid where his captors would tear the heart out of his living body so that the sun might eat and rise to fight again in the lagoon of Texcoco. Mythically equated with the Lake of the Moon, near the spring whose waters ran blue and red-symbolic of the glyph 'water-fire' [...] that stands for war-the Mexicans were to fill their mission as guardians the sun. (Wolf 1959: 131)

That this myth obscured and disguised reality is clear. The Mexicans were driven by their enemies to conquer the area of the myth. Yet we learn something of the justifying ideology of these people in their quest for power.

The tragic story of the Spanish rule for three centuries will have to await a longer study. But the Mexican myth that each age will end in disaster does not contradicted that prophecy. As Wolf concludes this book he asks whether Middle America will find its own voice or

whether it will wither away as Indianism declines in the face of the new utilitarianism of the new occupants? Thus men still remain torn between yesterday and tomorrow and Middle America remains in travail [...] the rooster has cried a coming dawn, but in the grey daybreak the shadows still lie in dark pools about doorway and alley. Somewhere an Indian elder bows to the four directions and invokes the rain givers, the earth-shakers in their mountainous domains. The mouth of the volcano still yawns; the future is not yet. It lies in the walk of that man shielding his face against the cold; in the gestures of that woman, fanning the embers of her fire and drawing her shawl more closely about her sleeping child; in that lonely figure, setting a signal around the railroad track. There is still time until the sun rises, but men scan the sky; for their lives are mortgaged to tomorrow. (Wolf 1959: 156)

We recall that Wolf's book appeared in 1959 and today there is still no answer to Hammel's warning concerning the future of indigenous cultures. 


\section{References}

Barrett, Stanley; Stokholm, Sean; Burke, Jeanette 2001. The idea of power and the power of ideas: Review essay. American Anthropologist 103(2): 468-480.

Cole, John W.; Wolf, Eric R. 1974. The Hidden Frontier: Ecology and Ethnicity in an Alpine Valley. New York: Academic Press.

Ghani, Ashraf 1995. Writing a history of power: An examination of Eric R. Wolf's anthropological quest. In: Schneider, Rapp 1995: 31-48.

Geertz, Clifford 1961. Studies in peasant life 1961: Community and society. In: Seigel, Bernard J. (ed.), Biennial Review of Society. Stanford: Stanford University Press, 1-41.

Hammel, Eugene A. 1993. The Yugoslav labyrinth. In: Kideckel, David A.; Halpern, Joel M. (eds.), The Yugoslav Conflict. Special issue of The Anthropology of East Europe Review 11(1/2): 35-42.

- 1994. Meeting the Minotaur. Anthropology Newsletter 35(4): 48.

Heydan, Robner M. 1993. The triumph of chauvinistic nationalism in Yugoslavia. In: Kideckel, David; Halpern, Joel (eds.), The Yugoslav Conflict. Special issue of The Anthropology of East Europe Review 11(1/2): 63-84.

Mintz, Sidney Wilfred; Wolf, Eric R. 1950. An analysis of ritual (Compadrazgo). Southwestern Journal of Anthropology 6(4): 341-368.

Nakhimovsky, Alexander D.; Nakhimovsky, Alice Stone (eds.) 1985. The Semiotics of Russian Cultural History: Essays by Iurii M. Lotman, Lidia Ia. Ginsburg, Boris A. Uspenskii. Ithaca: Cornell University Press.

Schneider, Jane 1995. Introduction: The analytic strategies of Eric Wolf. In: Schneider, Rapp 1995: 3-30.

Schneider, Jane; Rapp, Rayna (eds.) 1995. Articulating Hidden Histories: Exploring the Influence of Eric R. Wolf. Berkeley: University of California Press.

Wolf, Eric R. 1955. Types of Latin American peasantry. American Anthropologist 57: 452-471.

- 1956. Aspects of group relations in a complex society: Mexico. American Anthropologist 58: 1056-1078.

- 1957. Closed corporate communities in Mesoamerica and Central Java. Southwestern Journal of Anthropology 13(1): 1-18.

- 1958. The Virgin of Guadalupe. Journal of American Folklore 71: 34-39.

- 1959. Sons of the Shaking Earth. Chicago: University of Chicago Press.

- 1966. Peasants. Englewood: Prentice Hall.

- 1969a. American anthropologists and American society. In: Tyler, Stephen A. (ed.), Concepts and Assumptions in Contemporary Anthropology. (Southern Anthropological Proceedings 3.) Athens: University of Georgia Press, 3-11.

- 1969b. Society and symbols in Latin America and in the islamic Near East. Anthropological Quarterly 42(3): 287-301.

- 1969c. On peasant rebellions. International Journal of Social Sciences 21: 286-293.

- 1969d. Peasant Wars in the Twentieth Century. New York: Harper and Row.

- 1974. Introduction. In: Wolf, Eric R., Anthropology. New York: W. W. Norton, ix-xii. 
- 1982a. Culture: Panacea or problem? Northeastern Anthropological Newsletter (Fall): 1-10.

- 1982b. Europe and the People Without History. Berkeley: University of California Press.

- 1983. Introduction. In: Wolf, Eric R. (ed.), Religion, Power and Protest in Local Communities. New York: Mouton, 1-14.

- 1986. The vicissitudes of the closed corporate peasant community. American Ethnologist 13: 325-329.

- 1987. Cycles of violence: The anthropology of war and peace. In: Moore, Kenneth (ed.), Waymarks. Notre Dame: University of Notre Dame Press, 127150.

- 1988. Inventing society. American Ethnologist 15(4): 752-761.

- 1990. Facing power - old insights, new questions. AAA Distinguished lecture. American Anthropologist 92(3): 586-596.

- 1999. Envisioning Power: Ideologies of Dominance and Crisis. Berkeley: University of California Press.

- 2001. Pathways of Power: Building an Anthropology of the Modern World. (Silverman, Sydel, ed.) Berkeley: University of Chicago Press.

Wolf, Eric R.; Hansen, Edward C. 1972. The Human Condition in Latin America. New York: Oxford University Press.

\section{Эрик Вольф: пересекающий границы}

Статья является введением к большому исследованию о творчестве недавно умершего американского антрополога Эрика Вольфа (19231999). Автор считает Вольфа одним из величайших американских антропологов и собирается составить монографию по всем его работам, подчеркивая его поэтический стиль и "первопроходство". Труды Вольфа располагаются по трем пересекающимся периодам: 1) Эрик Вольф как поэт: сюда относится в основном его книга о Мексике; 2) охватывающее весь мир исследование о земледельцах, где подчеркивается роль истории, окружения, власти и т.п. (причем, Вольф здесь разрушает идею о статических и динамических культурах - столь любимых исследовательских объектах антропологов, - и таким образом навсегда изменяет облик всей антропологии); 3) период, дляшийся до его смерти и так и не закончившийся, - Вольф как философ и "пересекатель" границ. 


\section{Eric Wolf: piiride ületaja}

Artikkel on uurimuse sissejuhatuseks hiljuti lahkunud ameerika antropoloogi Eric Wolfi (1923-1999) töödest. Autor peab Wolfi üheks suurimaks ameerika antropoloogiks ja kavatseb koostada monograafia kõigist Wolfi töödest sellisest vaatepunktist, mis rõhutaks ta tundlikku, teedrajavat ja poeetilist arusaama. Wolfi töödes eristub kolm üksteist läbivat perioodi: (1) Eric Wolf kui poeet, eelkõige peamiselt ta töö Mehhikost; (2) kogu maailma hõlmav talurahva uurimus, mis rõhutab ajalugu, konteksti, võimu, jne. (seejuures juba päris alguses lammutas Wolf idee staatilistest ja isoleeritud kultuuridest, mida antropoloogid väga uurida armastavad, ning muutis sel moel alatiseks kogu antropoloogiat); (3) periood, mis ulatus ta surmani ja kunagi päriselt lõpule ei jõudnud — Wolf kui filosoof ja piiride ületaja. 